\title{
PENGARUH UKURAN PERUSAHAAN, PROFITABILITAS, SOLVABILITAS, LIKUIDITAS, DAN UKURAN KAP TERHADAP AUDIT REPORT LAG (STUDI EMPIRIS PADA PERUSAHAAN PROPERTI, REAL ESTATE, DAN KONSTRUKSI BANGUNAN YANG TERDAFTAR DI BURSA EFEK INDONESIA PERIODE 2011- 2015)
}

\author{
Sugi Tannuka \\ Program Maksi Fakultas Ekonomi \\ Universitas Tarumanagara, Jakarta \\ Email: sugitannuka@gmail.com
}

\begin{abstract}
The punctuality of audited financial report delivery is one measure for company owners, the community, especially investors for decision making. Therefore, this study was conducted to find out clearly and see more specific relationships regarding the effect of variables such as company size, profitability, solvency, liquidity, and the size of KAP that affect Audit Report Lag. This study uses secondary data in the form of financial statements and independent auditor reports obtained from the Indonesia Stock Exchange for the period of 2011-2015. The sampling technique in this study used the purposive sampling method. This technique takes samples from certain places and uses criteria for specific purposes, that are considered potential subjects for this study. The result of this study proves that the profitability and size of KAP have a significant effect on Audit Report Lag. Whereas, company size, solvency and liquidity have no significant effect on Audit Report Lag. This study also proves that company size, profitability, solvency, liquidity and KAP size simultaneously affect Audit Report Lag in significant manner.
\end{abstract}

Keywords :_Company Size, Profitability, Solvency, Liquidity, KAP size, and Audit Report Lag

\begin{abstract}
ABSTRAK
Ketepatan waktu penyampaian laporan keuangan auditan perusahaan publik merupakan salah satu ukuran bagi pemilik perusahaan, masyarakat khususnya investor guna pengambilan keputusan. Oleh karena itu, penelitian ini dilakukanuntuk mengetahui secara jelas dan melihat hubungan yang lebih spesifik mengenai pengaruh variabel ukuran perusahaan, profitabilitas, solvabilitas, likuiditas, dan ukuran KAP yang mempengaruhi Audit Report Lag.

Penelitian ini menggunakan data sekunder berupa laporan keuangan dan laporan auditor independen yang diperoleh dari Bursa Efek Indonesia periode 2011-2015. Teknik pengambilan sampel dalam penelitian ini menggunakan metode purposive sampling method. Teknik ini mengambil sampel dari tempat tertentu dan menggunakan kriteria untuk tujuan tertentu yang dianggap potensial dalam penelitian ini. Hasil penelitian ini membuktikan bahwa profitabilitas dan ukuran KAP berpengaruh signifikan terhadap Audit Report Lag. Sedangkan, ukuran perusahaan, solvabilitas dan likuiditas tidak berpengaruh signifikan terhadap Audit Report Lag. Penelitian ini juga membuktikan bahwa ukuran perusahaan, profitabilitas, solvabilitas, likuiditas, dan ukuran KAP secara simultan berpengaruh signifikan terhadap Audit Report Lag.
\end{abstract}

Kata kunci: ukuran perusahaan, profitabilitas, solvabilitas, likuiditas, ukuran KAP, dan Audit Report Lag

\section{PENDAHULUAN}

\section{Latar Belakang}

Audit Report Lag merupakan rentang waktu dalam menyelesaikan pekerjaan audit sampai tanggal diterbitkannya laporan audit. Audit Report Lag juga dikenal sebagai lamanya proses penyelesaian audit. Penelitian ini telah dilakukan di beberapa negara, termasuk di Indonesia. Penelitian yang dilakukan oleh Knechel dan Jeff (2001) menghasilkan rentang waktu Audit Report Lag rata-rata selama 68,09 hari, sedangkan 
PENGARUH UKURAN PERUSAHAAN, PROFITABILITAS,

Sugi Tannuka

SOLVABILITAS, LIKUIDITAS, DAN UKURAN

KAP TERHADAP AUDIT REPORT LAG (STUDI EMPIRIS

PADA PERUSAHAAN PROPERTI, REAL ESTATE,DAN

KONSTRUKSI BANGUNAN YANG TERDAFTAR DI

BURSA EFEK INDONESIA PERIODE 2011-2015)

Walker dan David (2006) menghasilkan rentang waktu Audit Report Lag rata-rata selama 63,8 hari.

Ukuran perusahaan merupakan salah satu faktor yang mempengaruhi Audit Report Lag. Ni Nyoman Trisna Dewi Ariyani dan I Ketut Budiartha (2014) berpendapat bahwa perusahaan besar memiliki sistem pengendalian internal yang sesuai dengan ukuran perusahaan tersebut. Sistem pengendalian internal dalam perusahaan yang besar akan menghabiskan lebih sedikit waktu dalam proses pengauditan. Selain itu, para pemilik perusahaan dan investor juga akan selalu menjaga reputasi perusahaannya dengan memberikan pengawasan (monitoring) yang ketat sehingga akan memperkecil kemungkinan terjadinya keterlambatan dalam mempublikasikan laporan keuangannya.

Selain ukuran perusahaan, umur perusahaan juga merupakan salah faktor yang mempengaruhi Audit Report Lag. Petronila (2007) mengemukakan semakin lama suatu perusahaan menjalankan usahanya maka jangka waktu pelaporan auditnya akan semakin cepat dalam publikasi laporan keuangan auditan karena kondisi perusahaan yang telah banyak menjadi perhatian masyarakat (investor) sehingga dapat mendorong manajemen untuk segera mempublikasikan laporan keuangan auditan guna pengambilan keputusan.

Profitabilitas menunjukkan kemampuan suatu perusahaan dalam menghasilkan laba secara efektif dan efisien (Petronila, 2007). Novice Lianto dan Budi Hartono Kusuma (2010) berpendapat bahwa semakin tinggi tingkat profitabilitas perusahaan maka akan menyebabkan semakin rendah Audit Report Lag. Perusahaan dengan tingkat profitabilitas yang tinggi cenderung membutuhkan proses pengauditan laporan keuangan yang lebih cepat karena adanya tuntutan untuk segera menyampaikan kabar baik (good news) secepatnya kepada publik. Carslaw dan Kaplan (1991) juga berpendapat bahwa perusahaan yang mengalami kerugian meminta auditornya untuk melakukan proses pengauditan lebih lambat dari seharusnya, akibatnya penyerahan laporan keuangan mengalami keterlambatan.

Solvabilitas menunjukkan kemampuan perusahaan untuk memenuhi segala kewajiban finansial perusahaan tersebut atau dapat dikatakan kemampuan perusahaan untuk bertahan dalam jangka waktu yang panjang. Menurut Indah Permata Sari et al., (2014), tingginya rasio solvabilitas mencerminkan suatu resiko keuangan yang sangat tinggi karena menunjukkan perusahaan tersebut tidak dapat melunasi kewajiban pokok maupun bunga atas utang. Lianto dan Budi (2010) berpendapat jika jumlah utang perusahaan lebih tinggi daripada aktiva yang dimiliki perusahaan maka cenderung meningkatkan kehati-hatian auditor di dalam mengaudit laporan keuangan sehingga membuat proses penyampaian laporan keuangan ke publik tertunda lebih lama.

Seperti halnya dengan solvabilitas, likuiditas menunjukkan kemampuan perusahaan untuk memenuhi kewajibannya. Likuiditas menunjukkan suatu kewajiban keuangan perusahaan yang harus segera dipenuhi, atau menunjukkan suatu kewajiban jangka pendek perusahaan yang harus segera dipenuhi. William et al., (2008) dalam Ni Luh Nyoman Adi Kusuma Dewi dan I Dewa Nyoman Wiratmaja (2016) menyatakan salah satu perhatian utama investor dan kreditur adalah likuiditas perusahaan. Hal ini menunjukkan bahwa perusahaan yang memiliki tingkat likuiditas yang sangat tinggi memiliki kondisi keuangan yang sangat baik karena dapat mencairkan aset yang tersedia di perusahaan untuk segera melunasi kewajiban ketika ditagih (jatuh tempo).

Ukuran KAP merupakan salah satu faktor yang mempengaruhi Audit Report Lag. Mujiyanto (2011) berpendapat bahwa KAP besar mendapatkan insentif yang besar sehingga proses audit dapat berjalan lebih cepat sehingga dapat mempertahankan reputasi mereka. Selain itu, KAP besar mempunyai lebih banyak sumber daya daripada KAP 
kecil, sehingga proses audit KAP besar lebih efisien dan efektif untuk menyelesaikan audit tepat waktu dibandingkan dengan KAP kecil.

Rentang waktu Audit Report Lag akan semakin panjang pada perusahaanperusahaan yang mendapatkan qualified opinion. Subekti dan Widiyanti (2004) mengemukakan bahwa rentang waktu Audit Report Lag akan lebih panjang pada perusahaan-perusahaan yang mendapatkan qualified opinion. Hal ini disebabkan atas proses pemberian opini qualified akan melibatkan negoisasi dengan manajemen perusahaan, konsultasi dengan partner yang lebih senior atau staf teknis dan perluasan ruang lingkup audit.

Perbedaan penelitian ini dengan penelitian terdahulu terletak pada sampel penelitian dan periode penelitian. Penelitian ini dilakukan pada perusahaan properti, real estate, dan konstruksi bangunan yang tercatat di Bursa Efek Indonesia pada periode 2011 sampai 2015. Perusahaan properti, real estate, dan konstruksi bangunan merupakan salah satu sektor industri yang terdaftar di Bursa Efek Indonesia. Sesuai dengan pembahasan di atas, pengembangan ini dilakukan untuk mengetahui secara jelas dan melihat hubungan yang lebih spesifik mengenai pengaruh variabel ukuran perusahaan, profitabilitas, solvabilitas, likuiditas, dan ukuran KAP yang mempengaruhi Audit Report Lag

\section{Kajian Teori}

Audit Report Lag didefinisikan sebagai berikut: "The time period between a company's fiscal year end and the date of the audit report." (Knechel dan Payne, 2001:139). Pendapat tersebut mengandung arti bahwa Audit Report Lag merupakan periode waktu antara akhir tahun fiskal dan tanggal laporan audit perusahaan. Hal tersebut dapat didefinisikan sebagai rentang waktu dalam menyelesaikan pekerjaan audit hingga tanggal diterbitkannya laporan audit. Ketepatan waktu atas penyajian laporan keuangan menjadi sinyal dari perusahaan yang menunjukkan adanya informasi yang bermanfaat dalam kebutuhan untuk pembuatan keputusan dari investor (Widati dan Septy, 2008:174). Keputusan yang diperoleh investor adalah keputusan untuk melakukan pembelian atau penjualan kepemilikan saham yang dimiliki. Semakin lama penundaan publikasi laporan keuangan maka semakin besar kemungkinan informasi tersebut dapat bocor kepada investor tertentu atau bahkan menimbulkan terjadinya Insider Trading dan rumor-rumor di bursa saham. Untuk menambah manfaat sebuah laporan keuangan maka perlu dilakukan audit atas laporan keuangan oleh akuntan publik yang memiliki kompetensi dan bersifat independen. Audit Report Lag tidak hanya berkaitan dengan internal perusahaan atau sinyal yang disampaikan oleh sebuah perusahaan melainkan juga berkaitan dengan akuntan publik yang digunakan. Ukuran KAP itu sendiri mempengaruhi ketepatan waktu dalam mempublikasi laporan keuangan auditan, selain faktor-faktor internal perusahaan seperti ukuran perusahaan, profitabilitas, solvabilitas, dan likuiditas.

\section{Pengaruh Ukuran Perusahaan Terhadap Audit Report Lag}

Ukuran perusahaan dalam penelitian ini terkait akan total aset sebuah perusahaan. Menurut Warren et al. (2008:52) dalam Meylisa Januari Iskandar \& Estralita Trisnawati (2010:177) mengungkapkan bahwa assets are resources owned by physical items, such as cash and supplies, or intangibles that have value. Sebuah perusahaan yang besar akan lebih cepat menyelesaikan proses audit dibandingkan dengan perusahaan yang kecil.

Menurut Meylisa Januari Iskandar \& Estralita Trisnawati (2010:184) menyatakan bahwa ukuran perusahaan dalam hal ini total aset tidak berpengaruh terhadap Audit Report Lag. Hal ini dikarenakan adanya internal control yang baik dan kemampuan 
PENGARUH UKURAN PERUSAHAAN, PROFITABILITAS,

SOLVABILITAS, LIKUIDITAS, DAN UKURAN

KAP TERHADAP AUDIT REPORT LAG (STUDI EMPIRIS

PADA PERUSAHAAN PROPERTI, REAL ESTATE,DAN

KONSTRUKSI BANGUNAN YANG TERDAFTAR DI

BURSA EFEK INDONESIA PERIODE 2011-2015)

perusahaan mendorong auditornya untuk secara tepat waktu menyelesaikan proses auditnya. Sedangkan, Rosmawati Endang Indriyani dan Supriyati (2012:199) menyatakan bahwa ukuran perusahaan mempengaruhi Audit Report Lag.

$\mathrm{H}_{1}$ : Ukuran perusahaan berpengaruh signifikan terhadap Audit Report Lag

\section{Pengaruh Profitabilitas Terhadap Audit Report Lag}

Menurut Novice Lianto dan Budi Hartono Kusuma (2010:99) menyatakan bahwa profitabilitas menunjukan sebuah keberhasilan perusahaan dalam menghasilkan keuntungan, dapat dikatakan profit merupakan kabar baik bagi perusahaan. Perusahaan yang menghasilkan tingkat profitabilitas yang tinggi membutuhkan waktu proses audit yang lebih cepat dikarenakan perusahaan ingin segera menyambaikan informasi baik kepada publik.

Berdasarkan hasil penelitian yang dilakukan oleh Novice Lianto dan Budi Hartono Kusuma (2010:103) menyatakan bahwa profitabilitas berpengaruh signifikan terhadap Audit Report Lag. Jika perusahaan memiliki profitabilitas yang lebih tinggi maka Audit Report Lag akan lebih pendek dibandingkan perusahaan yang tingkat profitabilitasnya lebih rendah. Sedangkan, Greta Juanita dan Rudji Satwiko (2012:39) menyatakan bahwa profitabilitas tidak berpengaruh terhadap Audit Report Lag.

$\mathrm{H}_{2}$ : Profitabilitas berpengaruh signifikan terhadap Audit Report Lag

\section{Pengaruh Solvabilitas Terhadap Audit Report Lag}

Carslaw dan Kaplan (1991) dalam Novice Lianto dan Budi Hartono Kusuma (2010:100) menyatakan bahwa proporsi relatif dari utang terhadap total aset menunjukkan kondisi keuangan dari sebuah perusahaan. Proporsi yang besar atas utang terhadap total aset akan cenderung meningkatkan kerugian dan meningkatkan kehati-hatian dari seorang auditor terhadap laporan keuangan perusahaan yang akan diaudit. Hal ini disebabkan karena jika proporsi dari utang tinggi maka tingkat resiko dari laporan keuangan tersebut juga tinggi. Perusahaan yang memiliki kondisi seperti ini cenderung melakukan missmanagement dan fraud.

Novice Lianto dan Budi Hartono Kusuma (2010:104) menyatakan bahwa solvabilitas berpengaruh secara signifikan terhadap Audit Report Lag. Proporsi atas utang terhadap total aset yang tinggi membuat seorang auditor perlu meningkatkan kecermatan yang lebih mendalam dalam proses auditnya terkait akan kelangsungan hidup perusahaan (going concern). Sedangkan, Ni Komang Ari Sumartini \& Ni Luh Sari Widhiyani (2014:405) menyatakan bahwa solvabilitas tidak berpengaruh signifikan terhadap Audit Report Lag. Walaupun sebuah perusahaan memiliki proporsi utang yang lebih besar, dalam penelitian ini tidak dapat membuktikan bahwa perusahaan tersebut harus memiliki tanggung jawab untuk dapat lebih cepat menyelesaikan audit laporan keuangannya.

$\mathrm{H}_{3}$ : Solvabilitas berpengaruh signifikan terhadap Audit Report Lag

\section{Pengaruh Likuiditas Terhadap Audit Report Lag}

Perusahaan yang memiliki tingkat likuiditas yang tinggi memiliki risiko yang lebih kecil terhadap kemungkinan terjadinya gagal bayar atas utang jangka pendek perusahaan (Listiana dan Susilo, 2012). Tingkat likuiditas yang tinggi menggambarkan perusahaan memiliki kinerja yang baik sehingga menghasilkan kabar baik (good news). Atas hal tersebut pihak manajemen akan meminta kepada pihak auditor untuk segera menyelesaikan laporan keuangan sehingga kabar baik (good news) dapat disampaikan secara tepat waktu. 
Hal tersebut sesuai dengan penelitian Almilia dan Setiady (2006) bahwa bahwa semakin besar rasio likuiditas, hal tersebut menunjukkan kondisi yang baik terhadap suatu perusahaan. Jika suatu perusahaan menyatakan kabar baik (good news), maka perusahaan akan cenderung untuk menyajikan laporan keuangan secara tepat waktu.

$\mathrm{H}_{4}$ : Likuiditas berpengaruh signifikan terhadap Audit Report Lag

\section{Pengaruh Ukuran KAP Terhadap Audit Report Lag}

Sebuah kantor akuntan publik besar membutuhkan waktu yang lebih cepat untuk melakukan penyelesaian audit, karena KAP tersebut dapat melaksanakan audit secara lebih efisien dan memiliki tingkat fleksibilitas waktu yang lebih tinggi untuk menyelesaikan audit tepat pada waktunya (Prabandari dan Rustiana, 2007 dalam Meylisa Januari Iskandar \& Estralita Trisnawati, 2010:178). Selain itu, waktu audit yang lebih cepat tersebut menunjukkan cara KAP besar untuk mempertahankan reputasi mereka.

Mujiyanto (2011) berpendapat bahwa ukuran KAP berpengaruh signifikan karena KAP besar mendapatkan insentif yang besar sehingga proses audit dapat berjalan lebih cepat sehingga dapat mempertahankan reputasi mereka. Selain itu, KAP besar mempunyai lebih banyak sumber daya daripada KAP kecil, sehingga proses audit KAP besar lebih efisien dan efektif untuk menyelesaikan audit tepat waktu dibandingkan dengan KAP kecil. Sedangkan, Greta Juanita \& Rudji Satwiko (2012:39) menyatakan bahwa ukuran KAP tidak berpengaruh terhadap Audit Report Lag.

$\mathrm{H}_{5}$ : Ukuran KAP berpengaruh signifikan terhadap Audit Report Lag

Model Penelitian dapat dilihat pada gambar berikut ini:

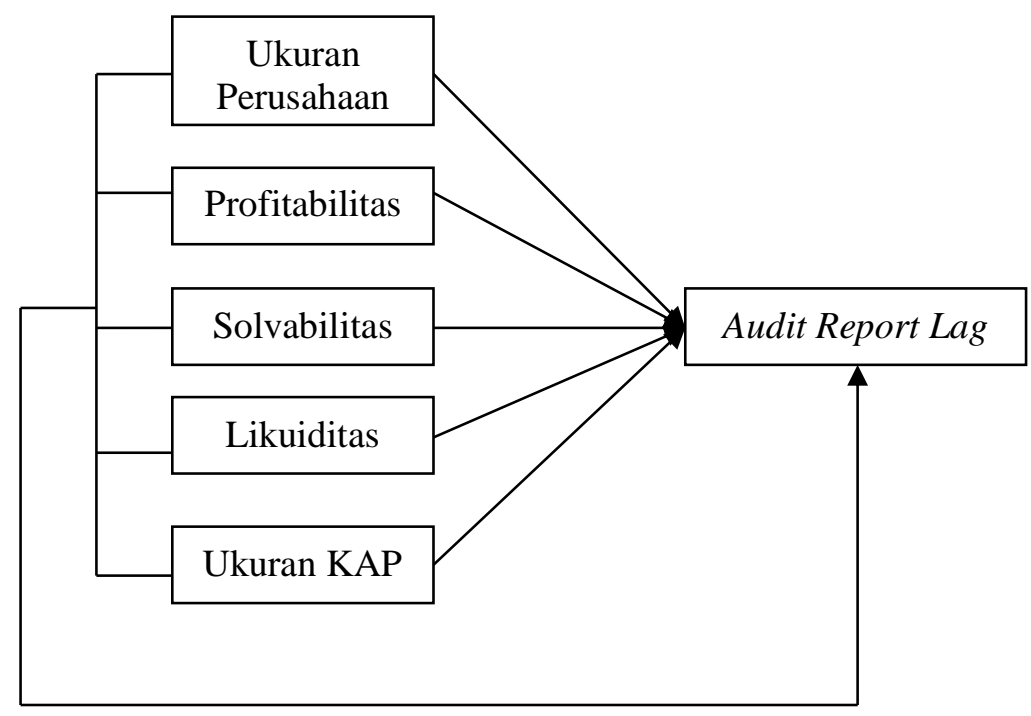

Gambar 1. Model Penelitian

\section{METODE PENELITIAN}

\section{Pemilihan Sampel dan Pengumpulan Data}

Objek penelitian yang digunakan adalah perusahaan properti, real estate, dan konstruksi bangunan yang terdaftar di Bursa Efek Indonesia periode 2011 sampai 2015. Pemilihan sampel menggunakan metode purposive sampling, yang dipilih berdasarkan kriteria yang terdaftar di BEI periode 2011 sampai 2015, memiliki laporan keuangan yang terpublikasi dan telah diaudit periode 2011 sampai 2015, dan menghasilkan laba dari 
PENGARUH UKURAN PERUSAHAAN, PROFITABILITAS,

SOLVABILITAS, LIKUIDITAS, DAN UKURAN

KAP TERHADAP AUDIT REPORT LAG (STUDI EMPIRIS

PADA PERUSAHAAN PROPERTI, REAL ESTATE,DAN

KONSTRUKSI BANGUNAN YANG TERDAFTAR DI

BURSA EFEK INDONESIA PERIODE 2011-2015)

tahun 2011 sampai 2015. Jumlah sampel yang memenuhi kriteria adalah 35 perusahaan, jumlah data yang digunakan adalah sebanyak 175 data penelitian. Data yang digunakan dalam penelitian ini adalah data sekunder yang berbentuk laporan keuangan, dan laporan auditor independen. Semua data tersebut diperoleh dari www.idx.co.id.

\section{Definisi Operasional dan Pengukuran Variabel}

Variabel independen yang digunakan dalam penelitian ini adalah ukuran perusahaan, profitabilitas, solvabilitas, likuiditas, dan ukuran KAP. Variabel dependen dalam penelitian ini adalah Audit Report Lag. Definisi operasional dan pengukuran variabel dalam penelitian dapat dijelaskan sebagai berikut:

Tabel 1. Definisi Operasional Variabel Penelitian

\begin{tabular}{|c|c|c|c|c|}
\hline No & Variabel & Definisi & Indikator & Skala \\
\hline 1. & $\begin{array}{l}\mathrm{Y}(\text { dependen })= \\
\text { Audit Report Lag }\end{array}$ & $\begin{array}{l}\text { Audit report lag means the time period between } \\
\text { a company's fiscal year end and the date of the } \\
\text { audit report. } \\
\text { (Knechel dan Payne (2001:139)). }\end{array}$ & $\begin{array}{l}\text { Jumlah hari } \\
\text { penyelesaian } \\
\text { (tanggal neraca- } \\
\text { tanggal audit) }\end{array}$ & Rasio \\
\hline 2. & $\begin{array}{l}\mathrm{X}_{1} \text { (independen) }= \\
\text { Ukuran perusahaan }\end{array}$ & $\begin{array}{l}\text { Banyak cara untuk mendefinisikan ukuran } \\
\text { perusahaan yaitu seperti jumlah karyawan, } \\
\text { volume penjualan, dan jumlah aset yang } \\
\text { dimiliki oleh suatu perusahaan. } \\
\text { (Longenecker }(2001: 16))\end{array}$ & Ln Total Asset & Rasio \\
\hline 3. & $\begin{array}{l}\mathrm{X}_{2}(\text { independen })= \\
\text { Profitabilitas }\end{array}$ & $\begin{array}{l}\text { Profitability ratios measure the income or } \\
\text { operating success of a company for a given } \\
\text { period of time. } \\
\text { (Weygandt et al., (2015:723)) }\end{array}$ & $\begin{array}{l}\text { Return on Assets } \\
(\text { ROA })=\text { net income } \\
\text { before tax / total } \\
\text { asset }\end{array}$ & Rasio \\
\hline 4. & $\begin{array}{l}\mathrm{X}_{3}(\text { independen })= \\
\text { Solvabilitas }\end{array}$ & $\begin{array}{l}\text { Solvency ratios measure the ability of a } \\
\text { company to survive over a long period of time. } \\
\text { (Weygandt et al., (2015:727)) }\end{array}$ & $\begin{array}{l}\text { Debt to Asset Ratio } \\
(\text { DAR })=\text { Total Debt } \\
\text { / Total Assets }\end{array}$ & Rasio \\
\hline 5. & $\begin{array}{l}\mathrm{X}_{4}(\text { independen })= \\
\text { Likuiditas }\end{array}$ & $\begin{array}{l}\text { Liquidity ratios measure the short-term ability } \\
\text { of the company to pay its maturing obligations } \\
\text { and to meet unexpected needs for cash. } \\
\text { (Weygandt et al., (2015:720)) }\end{array}$ & $\begin{array}{l}\text { Current Rasio }= \\
\text { Current assets / } \\
\text { current liabilities }\end{array}$ & Rasio \\
\hline 6. & $\begin{array}{l}\mathrm{X}_{5}(\text { independen })= \\
\text { Ukuran KAP }\end{array}$ & $\begin{array}{l}\text { KAP adalah badan usaha yang memiliki ijin } \\
\text { dari badan pengatur untuk menyediakan jasa } \\
\text { asurans dan jasa selain asurans seperti yang } \\
\text { tercantum dalam standar profesi, dapat } \\
\text { berbentuk perseorangan/persekutuan. } \\
\text { (IAPI }(2013 ; 4) \text { ) } \\
\text { Ukuran KAP digolongkan berdasarkan jumlah } \\
\text { partner suatu KAP. }\end{array}$ & $\begin{array}{l}\text { a. } \text { Partner } \geq 10(1) \\
\text { b. Partner }<10(0)\end{array}$ & $\begin{array}{l}\text { Nominal } \\
\text { (dummy) }\end{array}$ \\
\hline
\end{tabular}

\section{HASIL DAN PEMBAHASAN}

Berdasarkan data penelitian yang ada maka diperoleh hasil statistik deskriptif sebagai berikut: 
Tabel 2. Hasil Uji Descriptive Statistics

\begin{tabular}{|l|r|r|r|r|r|}
\hline & $\mathrm{N}$ & Minimum & Maximum & Mean & Std. Deviation \\
\hline ARL & 175 & 30.00 & 112.00 & 73.5714 & 14.88285 \\
SIZE_COM & 175 & 24.84 & 31.35 & 29.1047 & 1.15387 \\
ROA & 175 & .00 & .82 & .0905 & .07445 \\
DAR & 175 & .08 & 4.70 & .4936 & .36080 \\
CR & 175 & .24 & 10.03 & 2.0584 & 1.43490 \\
SIZE_KAP & 175 & 0 & 1 & .84 & .368 \\
Valid N (listwise) & 175 & & \multicolumn{3}{|c|}{} \\
\hline
\end{tabular}

Sumber : Hasil Olah Data Sekunder dengan SPSS, 2017

Rata-rata Audit Report Lag (ARL) adalah 73,571 hari, jumlah minimum 30 hari, jumlah maksimum 112 hari dengan standar deviasi 14,883. Hasil pengujian statistik deskriptif menunjukkan bahwa hampir semua perusahaan properti, real estate, dan konstruksi bangunan yang terdaftar di BEI menyampaikan laporan keuangan secara tepat waktu berdasarkan keputusan Bapepam dan LK. Rata-rata ukuran perusahaan sebesar 29,104, nilai minimum 24,84, nilai maksimum 31,35 dengan standar deviasi 1,153 . Berdasarkan hasil pengujian tersebut dapat dikatakan bahwa perusahaan dalam sampel penelitian memiliki ukuran yang cukup besar jika dinilai dari total aset perusahaan. Nilai rata-rata profitabilitas adalah 0,0905 , nilai minimum 0,00 , nilai maksimum 0,82 dengan standar deviasi 0,07445. Nilai rata-rata solvabilitas adalah 0,4936 , nilai minimum 0,08 , nilai maksimum 4,70 dengan standar deviasi 0,36080. Berdasarkan hasil pengujian tersebut dapat disimpulkan bahwa rata-rata utang yang dimiliki perusahaan sampel tidak begitu besar dibandingkan dari total aset yang dimiliki oleh perusahaan. Nilai rata-rata likuiditas adalah 2,0584, nilai minimum 0,24, nilai maksimum 10,03 dengan standar deviasi 1,43489. Ukuran KAP (SIZE_KAP) merupakan variabel dummy maka pengujian dilakukan secara terpisah. Ukuran KAP dilihat dari dua kategori, yaitu KAP besar atau KAP kecil. Berikut hasil pengujian statistik deskriptif yang telah dilakukan

Tabel 3. Hasil Uji Deskriptif Variabel Dummy SIZE_KAP

\begin{tabular}{|c|c|c|c|c|c|}
\hline & & Frequency & Percent & Valid Percent & $\begin{array}{c}\text { Cumulative } \\
\text { Percent }\end{array}$ \\
\hline \multirow[t]{3}{*}{ Valid } & 0 & 28 & 16,0 & 16,0 & \multirow{3}{*}{$\begin{array}{r}16,0 \\
100,0\end{array}$} \\
\hline & 1 & 147 & 84,0 & 84,0 & \\
\hline & Total & 175 & 100,0 & 100,0 & \\
\hline
\end{tabular}

Keterangan :

0 : KAP kecil

1 : KAP besar

Sumber : Hasil Olah Data Sekunder dengan SPSS, 2017

Berdasarkan tabel 3, perusahaan yang termasuk menggunakan KAP kecil ada 28 perusahaan, dan yang menggunakan KAP besar ada 147 perusahaan. 
KAP TERHADAP AUDIT REPORT LAG (STUDI EMPIRIS

PADA PERUSAHAAN PROPERTI, REAL ESTATE,DAN

KONSTRUKSI BANGUNAN YANG TERDAFTAR DI

BURSA EFEK INDONESIA PERIODE 2011-2015)

Tabel 4. Hasil Uji One-Sample Kolmogorov-Smirnov Test

\begin{tabular}{|ll|r|r|r|r|r|r|}
\hline & & \multicolumn{1}{c|}{ ARL } & SIZE_COM & \multicolumn{1}{c|}{ ROA } & DAR & \multicolumn{1}{c|}{ CR } & SIZE_KAP \\
\hline $\mathrm{N}$ & 175 & 175 & 175 & 175 & 175 & 175 \\
Normal & Mean & 65.3943 & 48.1143 & .3607 & .1794 & 3.4499 & .58 \\
Parameters ${ }^{\mathrm{a}, \mathrm{b}}$ & Std. & 22.41610 & 4.80045 & .22040 & .50980 & .50966 & .299 \\
& Deviation & & & & & & \\
Most Extreme & Absolute & .090 & .075 & .087 & .043 & .093 & .053 \\
Differences & Positive & .090 & .075 & .087 & .043 & .093 & .053 \\
& Negative & -.088 & -.048 & -.074 & -.043 & -.052 & -.045 \\
Kolmogorov-Smirnov Z & 1.197 & .995 & 1.155 & .571 & 1.236 & .699 \\
Asymp. Sig. (2-tailed) & .114 & .275 & .139 & .901 & .094 & .713 \\
\hline
\end{tabular}

a. Test distribution is Normal.

b. Calculated from data.

Sumber : Hasil Olah Data Sekunder dengan SPSS, 2017

Berdasarkan tabel 4, menunjukkan nilai sig. $\geq 0.05$ untuk seluruh variabel penelitian, maka dapat dikatakan bahwa distribusi data untuk setiap variabel yang diteliti adalah berdistribusi secara normal.

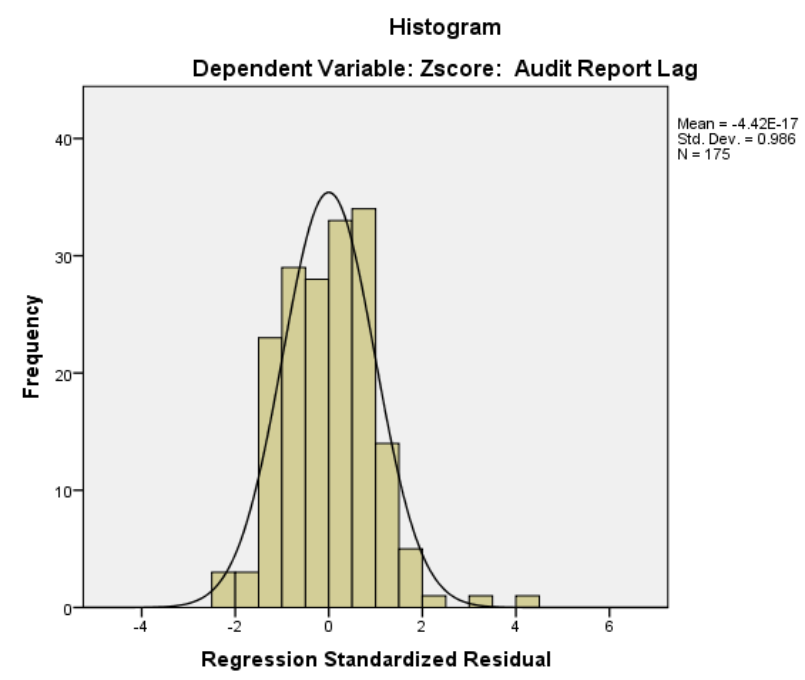

Gambar 2. Histogram

Gambar 2 tersebut merupakan histogram yang dihasilkan, yang menunjukan distribusi data nilai residu (error) menunjukkan distribusi normal (lihat gambar berbentuk lonceng). 


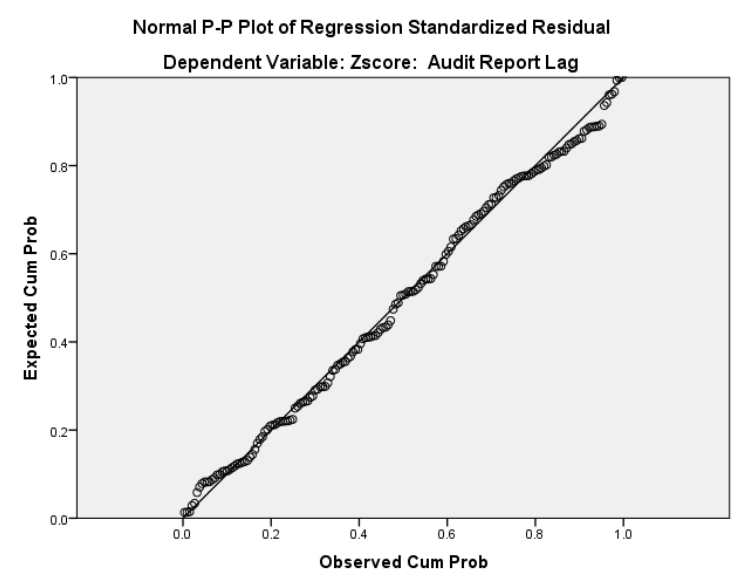

Gambar 3. Normal Probability Plot (P-P Plot)

Gambar 3 menunjukkan Normal Probability Plot (P-P Plot) yang dihasilkan, terlihat sebaran error berupa dot masih disekitar garis lurus. Hal ini menunjukkan bahwa distribusi data dapat dikatakan berdistribusi normal.

Berdasarkan hasil uji normalitas dengan metode Kolmogorov-Smirnov, histogram dan plot (P-P Plot) atas persyaratan pengukuran yang telah dibahas diatas, maka dapat disimpulkan bahwa distribusi data adalah normal.

Tabel 5. Hasil Pengujian Multikolinearitas

Coefficients ${ }^{\mathrm{a}}$

\begin{tabular}{|c|c|c|c|c|c|c|c|}
\hline \multirow[b]{2}{*}{ Model } & \multicolumn{2}{|c|}{\begin{tabular}{|c|} 
Unstandardized \\
Coefficients
\end{tabular}} & \multirow{2}{*}{$\begin{array}{c}\begin{array}{r}\text { Standardized } \\
\text { Coefficients }\end{array} \\
\text { Beta }\end{array}$} & \multirow[b]{2}{*}{$\mathrm{T}$} & \multirow[b]{2}{*}{ Sig. } & \multicolumn{2}{|c|}{$\begin{array}{c}\text { Collinearity } \\
\text { Statistics }\end{array}$} \\
\hline & $\mathrm{B}$ & Std. Error & & & & Tolerance & VIF \\
\hline 1 (Constant) & .740 & .043 & & 17.132 & .000 & & \\
\hline SIZE_COM & .060 & .044 & .105 & 1.378 & .170 & .984 & 1.016 \\
\hline ROA & .030 & .045 & .053 & .677 & .500 & .944 & 1.059 \\
\hline DAR & -.022 & .044 & -.038 & -.498 & .619 & .989 & 1.011 \\
\hline $\mathrm{CR}$ & .018 & .044 & .032 & .415 & .679 & .983 & 1.018 \\
\hline SIZE_KAP & -.063 & .044 & -.111 & -1.434 & .153 & .962 & 1.040 \\
\hline
\end{tabular}

a. Dependent Variable: RES2

Sumber : Hasil Olah Data Sekunder dengan SPSS, 2017

Berdasarkan hasil pengujian multikolinearitas pada tabel 4.5 menunjukan semua variabel-variabel independen memiliki nilai Variance Inflation Factor (VIF) kurang dari 10 yaitu : SIZE_COM $(1,016)$; ROA $(1,059)$; DAR $(1,011)$; CR $(1,018)$ dan SIZE_KAP $(1,040)$. Selain itu, nilai Tolerance Value lebih dari 0,1 yaitu : SIZE_COM $(0,984)$; ROA $(0,944)$; DAR $(0,989)$; CR $(0,983)$ dan SIZE_KAP $(0,962)$.

Dari pembahasan hasil pengujian multikolinearitas pada tabel 4.5, menggambarkan tidak adanya hubungan antar variabel independen dengan nilai VIF $<10$ dan Tolerance $>0,1$. Dapat disimpulkan bahwa model regresi penelitian tersebut tidak mengalami multikolinearitas. 
Tabel 6. Hasil Uji Autokorelasi

Model Summary ${ }^{\mathrm{b}}$

\begin{tabular}{|r|r|r|r|r|r|}
\hline Model & $\mathrm{R}$ & $\mathrm{R}$ Square & $\begin{array}{c}\text { Adjusted R } \\
\text { Square }\end{array}$ & $\begin{array}{c}\text { Std. Error of } \\
\text { the Estimate }\end{array}$ & $\begin{array}{c}\text { Durbin- } \\
\text { Watson }\end{array}$ \\
\hline 1 & $.349^{\mathrm{a}}$ & .122 & .096 & .95088842 & 1.878 \\
\hline
\end{tabular}

a. Predictors: (Constant), SIZE_KAP, DAR, SIZE_COM, CR, ROA

b. Dependent Variable: ARL

Sumber : Hasil Olah Data Sekunder dengan SPSS, 2017

Berdasarkan hasil uji autokorelasi pada tabel 6 , menunjukan nilai $\mathrm{d}=1,878$, nilai ini akan dibandingkan dengan nilai tabel signifikan 5\%, dengan $\mathrm{n}=175$ dan jumlah variabel independen $5(\mathrm{k}=5)$. Dengan melihat tabel Durbin-Watson maka didapatkan nilai $\mathrm{dL}=1,6943$ dan nilai $\mathrm{dU}=1,8117$. Maka, dapat dilihat bahwa nilai $\mathrm{d}>1,8117$ maka tidak terdapat autokorelasi positif. Serta nilai (4-d) > 1,8117 maka tidak terdapat autokorelasi negatif.

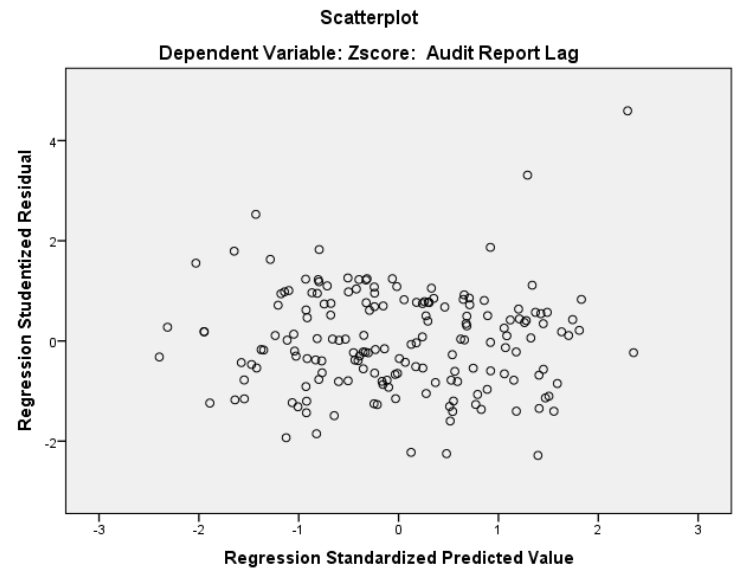

Gambar 4. Hasil Uji Heteroskedastisitas

Berdasarkan gambar 4 menunjukan bahwa titik-titik scatterplot tersebar rata dan tidak membentuk pola tertentu. Hal ini berarti pada setiap prediksi, nilai residu memiliki variasi residu yang sama. Maka, dapat disimpulkan bahwa model regresi penelitian ini bebas dari heteroskedastisitas.

\section{Tabel 7. Hasil Uji F}

ANOVA $^{\mathrm{b}}$

\begin{tabular}{|l|r|r|r|r|r|}
\hline Model & Sum of Squares & Df & Mean Square & F & \multicolumn{1}{|c|}{ Sig. } \\
\hline 1 Regression & 21.192 & 5 & 4.238 & 4.688 & $.000^{\mathrm{a}}$ \\
Residual & 152.808 & 169 & .904 & & \\
Total & 174.000 & 174 & & & \\
\hline
\end{tabular}

a. Predictors: (Constant), SIZE_KAP, DAR, SIZE_COM, CR, ROA

b. Dependent Variable: ARL

Sumber : Hasil Olah Data Sekunder dengan SPSS, 2017

Tabel 7 menunjukkan nilai $\mathrm{F}$ hitung adalah 4,688 dengan tingkat signifikansi 0,000. Nilai probabilitas adalah 0,000 lebih kecil dari 0,05 , maka model regresi bisa dipakai untuk memprediksi ARL (Audit Report Lag) atau dapat dikatakan SIZE_COM (Ukuran Perusahaan), ROA (Profitabilitas), DAR (Solvabilitas), CR (Likuiditas) dan 
SIZE_KAP (Ukuran KAP) bersama-sama berpengaruh terhadap ZARL (Audit Report Lag).

Tabel 8. Hasil Uji t

Coefficients $^{\mathrm{a}}$

\begin{tabular}{|c|c|c|c|c|c|c|c|}
\hline \multirow[b]{2}{*}{ Model } & \multicolumn{2}{|c|}{$\begin{array}{c}\text { Unstandardized } \\
\text { Coefficients }\end{array}$} & \multirow{2}{*}{$\begin{array}{c}\begin{array}{r}\text { Standardized } \\
\text { Coefficients }\end{array} \\
\text { Beta }\end{array}$} & \multirow[b]{2}{*}{$\mathrm{T}$} & \multirow[b]{2}{*}{ Sig. } & \multicolumn{2}{|c|}{$\begin{array}{c}\text { Collinearity } \\
\text { Statistics }\end{array}$} \\
\hline & $\mathrm{B}$ & Std. Error & & & & Tolerance & VIF \\
\hline 1 (Constant) & $\begin{array}{r}-1.762 \mathrm{E}- \\
15\end{array}$ & .072 & & .000 & 1.000 & & \\
\hline SIZE_COM & .122 & .073 & .122 & 1.681 & .095 & .984 & 1.016 \\
\hline ROA & .225 & .074 & .225 & 3.037 & .003 & .944 & 1.059 \\
\hline DAR & .013 & .072 & .013 & .177 & .860 & .989 & 1.011 \\
\hline $\mathrm{CR}$ & .131 & .073 & .131 & 1.808 & .072 & .983 & 1.018 \\
\hline SIZE_KAP & .186 & .074 & .186 & 2.525 & .012 & .962 & 1.040 \\
\hline
\end{tabular}

a. Dependent Variable: ZARL

Sumber : Hasil Olah Data Sekunder dengan SPSS, 2017

Nilai signifikansi variabel ukuran perusahaan adalah sebesar 0,095. Hal ini menunjukkan $\mathrm{H}_{1}$ ditolak yang berarti bahwa ukuran perusahaan tidak berpengaruh signifikan terhadap Audit Report Lag. Hal ini disebabkan bahwa Perusahaan yang telah terdaftar di BEI akan diawasi oleh investor, regulator, dan berbagai pihak yang memiliki kepentingan atas laporan keuangan perusahaan. Oleh karena itu, perusahaan dituntut untuk dapat menyelesaikan proses audit laporan keuangan dan melakukan penyampaian laporan keuangan perusahaan secara tepat waktu. Hasil penelitian ini konsisten dengan penelitian yang dilakukan oleh Meylisa Januari Iskandar dan Estralita Trisnawati (2010), Novice Lianto dan Budi Hartono Kusuma (2010) dan Greta Juanita dan Rudji Satwiko (2010).

Nilai signifikansi variabel profitabilitas adalah sebesar 0,003. Hal ini menunjukkan $\mathrm{H}_{2}$ diterima yang berarti bahwa profitabilitas berpengaruh signifikan terhadap Audit Report Lag. Hal ini disebabkan bahwa Perusahaan dengan tingkat profitabilitas yang tinggi membutuhkan proses pengauditan laporan keuangan yang lebih cepat karena adanya tuntutan untuk segera menyampaikan kabar baik (good news) secepatnya kepada publik (investor). Hasil penelitian ini konsisten dengan penelitian yang dilakukan oleh Novice Lianto dan Budi Hartono Kusuma (2010) dan Ni Nyoman Trisna Dewi Ariyani dan I Ketut Budiartha (2014).

Nilai signifikansi variabel solvabilitas adalah sebesar 0,860 . Hal ini menunjukkan bahwa $\mathrm{H}_{3}$ ditolak yang berarti bahwa solvabilitas tidak berpengaruh signifikan terhadap Audit Report Lag. Hal ini disebabkan ketika auditor melaksanakan prosedur audit bagi sebuah perusahaan yang memiliki total utang yang besar ataupun total utang yang kecil tidak akan mempengaruhi proses penyelesaian audit laporan keuangan perusahaan. Pengungkapan suatu peristiwa pada catatan atas laporan keuangan merupakan hal yang penting. Pengungkapan yang memadai dapat membantu auditor dalam melaksanakan pekerjaannya. Hasil penelitian ini konsisten dengan penelitian yang dilakukan oleh $\mathrm{Ni}$ Komang Ari Sumartini dan Ni Luh Sari Widhiyani (2014).

Nilai signifikansi variabel likuiditas adalah sebesar 0,072. Hal ini menunjukkan bahwa $\mathrm{H}_{4}$ ditolak yang berarti bahwa likuiditas tidak berpengaruh signifikan terhadap Audit Report Lag. Hal ini disebabkan perusahaan menginginkan penyampaian laporan keuangan secara tepat waktu tanpa mempertimbangkan tingkat likuiditas yang tinggi atau 
KAP TERHADAP AUDIT REPORT LAG (STUDI EMPIRIS

PADA PERUSAHAAN PROPERTI, REAL ESTATE,DAN

KONSTRUKSI BANGUNAN YANG TERDAFTAR DI

BURSA EFEK INDONESIA PERIODE 2011-2015)

rendah, hal ini bertujuan untuk memberikan informasi kepada pihak ketiga (kreditor) mengenai kemampuan sebuah perusahaan dalam memenuhi kewajibannya. Selain itu, dalam menyajikan laporan keuangan, manajemen perusahaan harus melaporan dan memperhatikan kondisi perusahaan secara keseluruhan (tidak hanya operasional jangka pendek). Seorang auditor juga harus melakukan audit secara menyeluruh baik bersifat jangka pendek ataupun jangka panjang. Hasil penelitian ini konsisten dengan penelitian yang dilakukan oleh Listiana dan Susilo (2012) dan Fitri dan Nazira (2009).

Nilai signifikansi variabel ukuran KAP adalah sebesar 0,012. Hal ini menunjukkan bahwa $\mathrm{H}_{5}$ diterima yang berarti bahwa likuiditas berpengaruh signifikan terhadap Audit Report Lag. Hal ini disebabkan KAP besar akan memiliki waktu yang lebih cepat dalam menyelesaikan proses audit dibandingkan dengan KAP kecil. Hal ini dikarenakan KAP besar umumnya telah memiliki sumber daya yang lebih besar, dari segi kompetensi, keahlian dan kemampuan auditor maupun fasilitas dan sistem pengaditan dibandingkan dengan KAP kecil sehingga proses penyelesaian pekerjaan audit akan lebih efektif dan efisien. Hasil penelitian ini konsisten dengan penelitian yang dilakukan Meylisa Januari Iskandar dan Estralita Trisnawati (2010).

Tabel 8. Hasil Uji Koefisien Determinasi

Variables Entered/Removed ${ }^{\mathrm{b}}$

\begin{tabular}{|l|c|c|l|}
\hline Model & Variables Entered & $\begin{array}{l}\text { Variables } \\
\text { Removed }\end{array}$ & Method \\
\hline 1 & SIZE_COM, ROA, DAR , CR, SIZE_KAP & & .Enter \\
\hline
\end{tabular}

a. All requested variables entered.

b. Dependent Variable: ZARL

Model Summaryb

\begin{tabular}{|l|c|r|r|r|r}
\hline Model & $\mathrm{R}$ & R Square & Adjusted R Square & Std. Error of the Estimate & Durbin-Wats \\
\hline 1 & $.349^{\mathrm{a}}$ & .122 & .096 & .95088842 & $1 . \varepsilon$ \\
\hline
\end{tabular}

a. Predictors: (Constant), ZSIZE_KAP, ZDAR, ZSIZE_COM, ZCR, ZROA

b. Dependent Variable: ZARL

Sumber : Hasil Olah Data Sekunder dengan SPSS, 2017

Dalam penelitian ini akan digunakan nilai Adjusted $\mathrm{R}^{2}$ karena terdapat lebih dari dua variabel independen. Hal ini dilakukan untuk menghindari bias nilai $\mathrm{R}^{2}$ akibat banyaknya variabel independen dalam persamaan regresi. Angka Adjusted $\mathrm{R}^{2}$ adalah 0,096. Nilai ini menunjukkan bahwa Audit Report Lag dipengaruhi oleh ukuran perusahaan, profitabilitas, solvabilitas, likuiditas dan ukuran KAP sebesar 9,6\%, sedangkan 90,4\% sisanya dipengaruhi oleh variabel-variabel lain diluar penelitian.

\section{KESIMPULAN DAN SARAN}

Berdasarkan hasil penelitian yang telah dilakukan, maka dapat ditarik simpulan bahwa profitabilitas dan ukuran KAP berpengaruh signifikan terhadap Audit Report Lag. Ukuran perusahaan, solvabilitas, dan likuiditas tidak berpengaruh signifikan terhadap Audit Report Lag.

Keterbatasan penelitian ini adalah pemilihan sampel yang hanya terbatas pada perusahaan properti, real estate, dan konstruksi bangunan. Penelitian ini hanya menggunakan lima variabel independen, nilai adjusted $\mathrm{R}^{2}$ yang rendah mengindikasikan masih terhadap banyak variabel independen yang mempengaruhi Audit Report Lag. 
Sehubungan dengan keterbatasan yang ada maka saran penelitian selanjutnya dapat memperluas sampel dengan meneliti kelompok industri yang berbeda dan dapat menambahkan variabel independen lain, serta peneliti dapat mempertimbangkan penggunaan variabel kontrol ataupun variabel moderasi untuk mengetahui pengaruh variabel independen terhadap Audit Report Lag.

\section{REFERENSI}

Afify, H. A. E. (2009). Determine of Audit Report Lag Does Implementing Corporate Governance Have Any Impact? Empirical Evidence From Egypt. Journal of Applied Accounting Research. (Vol. 10. No. 1). pp. 56-86.

Ariyani, Ni Nyoman Trisna Dewi dan I Ketut Budiartha. (2014). Pengaruh Profitabilitas, Ukuran Perusahaan, Kompleksitas Operasi Perusahaan, dan Reputasi KAP Terhadap Audit Report Lag Pada Perusahaan Manufaktur. E-Jurnal Akuntansi Universitas Udayana. (Vol. 8. No. 2). pp. 217-230.

Ayushabrina, Fina dan Rahardjo, Shiddiq Nur. (2014). Pengaruh Internal dan Eksternal Perusahaan Terhadap Audit Report Lag (Studi Empiris Pada Perusahaan Nonfinancial yang Terdaftar di Bursa Efek Indonesia tahun 2012). Diponegoro Journal of Accounting. (Vol. 3. No. 2). Hlm. 1-12.

Carslaw, C.A.P.N and Kaplan, S.E. (1991). An Examination of Audit Delay : Further Evidence from New Zealand. Accounting \& Business Research. pp. 21-32.

Dewi, Ni Luh Nyoman Adi Kusuma dan Wiratmaja, I Dewa Nyoman. (2016). Likuiditas Sebagai Pemoderasi Pengaruh Ukuran Perusahaan Pada Audit Report Lag. EJurnal Akuntansi Universitas Udayana. (Vol. 15. No.3). pp. 2297-2323.

Fitri, Fauziah Aida dan Nazira. (2009). Analisis Ketepatan Waktu Penyampaian Laporan Keuangan Kepada Publik : Studi Empiris pada Perusahaan Manufaktur yang Terdaftar di Bursa Efek Indonesia. Jurnal Telaah dan Riset Akuntansi. (Vol.2. No.2). Hlm. 198-214.

Ghozali, Imam. (2011). Aplikasi Analisis Multivariate Dengan Program IBM SPSS 19. Edisi 5. Semarang: Badan Penerbit Universitas Diponegoro.

Ikatan Akuntan Indonesia. (2011). Standar Profesional Akuntan Publik. Jakarta: Salemba Empat.

Ikatan Akuntan Publik Indonesia. (2011). Directory 2011. Jakarta.

Ikatan Akuntan Publik Indonesia. (2012). Directory 2012. Jakarta.

Ikatan Akuntan Publik Indonesia. (2013). Directory 2013. Jakarta.

Ikatan Akuntan Publik Indonesia. (2014). Directory 2014. Jakarta.

Ikatan Akuntan Publik Indonesia. (2015). Directory 2015. Jakarta.

Indriyani, Rosmawati Endang dan Supriyati. (2012). Faktor-Faktor yang Mempengaruhi Audit Report Lag Perusahaan Manufaktur di Indonesia dan Malaysia. The Indonesian Accounting Review. (Vol.2.No. 2). pp. 185-202.

Iskandar, Meylisa Januari dan Trisnawati, Estralita. (2010). Faktor-Faktor yang Mempengaruhi Audit Report Lag Pada Perusahaan yang Terdaftar di Bursa Efek Indonesia. Jurnal Bisnis dan Akuntansi. (Vol. 12. No. 3). Hlm. 175-186. 
PENGARUH UKURAN PERUSAHAAN, PROFITABILITAS,

Sugi Tannuka

SOLVABILITAS, LIKUIDITAS, DAN UKURAN

KAP TERHADAP AUDIT REPORT LAG (STUDI EMPIRIS

PADA PERUSAHAAN PROPERTI, REAL ESTATE,DAN

KONSTRUKSI BANGUNAN YANG TERDAFTAR DI

BURSA EFEK INDONESIA PERIODE 2011-2015)

Jensen, M. C and Meckling, W.H. (1976). Theory of the Firm : Managerial Behavior, Agency Costs and Ownership Structure. Journal of Financial Economics. (V. 3, No. 4). pp. 305-360.

Juanita, Greta dan Satwiko, Rudji. (2012). Pengaruh Ukuran Kantor Akuntan Publik, Kepemilikan, Laba Rugi, Profitabilitas, dan Solvabilitas Terhadap Audit Report Lag. Jurnal Bisnis dan Akuntansi. (Vol. 14. No. 1). Hlm. 31-40.

KEP-346/BL/2011 Tentang Penyampaian Laporan Keuangan Berkala Emiten atau Perusahaan Publik.

Knechel, W. Robert and Payne, Jeff L. (2001). Additional Evidence on Report Lag. (Vol. 2 No. 1). Auditing: A Journal of Practices and Theory.

Lianto, Novice dan Kusuma, Budi Hartono. (2010). Faktor-Faktor yang Berpengaruh Terhadap Audit Report Lag. Jurnal Bisnis dan Akuntansi. (Vol. 12. No. 2). Hlm. 97-106.

Longenecker, J.G. (2001). Kewirausahaan : Manajemen Usaha Kecil. Jakarta: Salemba Empat.

Mulyadi. (2002). Auditing. Buku 1. Edisi 6. Jakarta: Salemba Empat.

Mustofa. (2014). Manajemen Modern Bisnis Kantor Akuntan Publik. Jakarta : Kompas.

Petronila, Thio Anastasia. (2007). Analisis Skala Perusahaan, Opini Audit, dan Umur Perusahaan Atas Audit Report Lag. Akuntabilitas. Hlm. 129-141.

Riahi, Belkaoui, Ahmed . (2004). Accounting Principles. $5^{\text {th }}$ edition. London: Thomson Learning.

Santosa, Singgih. (2017). Menguasai Statistik dengan SPSS 24. Jakarta : PT Elex Media Komputindo.

Sari, Indah Permata. Setiawan, R.Adri. dan Ilham, Elfi. (2014). Pengaruh Ukuran Perusahaan, Solvabilitas, dan Reputasi KAP Terhadap Audit Delay Pada Perusahaan Properti dan Real Estate di Bursa Efek Indonesia Periode 2009-2012. JOM FEKON. (Vol. 1. No. 2).

Sarwono, Jonathan. (2017). Mengenal Prosedur-Prosedur Populer dalam SPSS 23. Jakarta : PT Elex Media Komputindo.

Schroeder, Richard G. Clark, Myrtle W, and Cathey, Jackson. 2001. Accounting Theory and Analysis. $7^{\text {th }}$ edition. New York: John Wileyand Son, Inc.

Spence, Michael. (1973). Job Market Signaling. The Quarterly Journal of Economics, 87,( 3) (Aug., 1973), pp. 355-374.

Sugiyono. (2012). Metode Penelitian Kuantitatif Kualitatif dan R\&D. Bandung: Alfabeta.

Sugiyono. (2012). Metode Penelitian Bisnis. Bandung: Alfabeta.

Suharli, M., dan Rachpriliani, A. (2006). Studi Empiris Faktor yang Berpengaruh Terhadap Ketepatan Wktu Pelaporan Keuangan. Jurnal Bisnis dan Akuntansi. (Vol.8. No.1). Hlm. 34-35.

Sumartini, Ni Komang Ari dan Budiartha, I Ketut. (2014). Pengaruh Profitabilitas, Ukuran Perusahaan, Kompleksitas Operasi Perusahaan, dan Reputasi KAP Terhadap Audit Report Lag Pada Perusahaan Manufaktur. E-jurnal Akuntansi Universitas Udayana. (Vol. 9. No. 1). pp. 392-409.

Walker, Angela dan David Hay. (2006). Non-Audit Service and Knowledge Spillovers : An Investigation of Audit Report Lag. Research Paper. 
Weygandt, Jerry J. Kimmel, Paul D. And Kieso, Donald E. (2015). Financial Accounting 3e. IFRS Edition. Wiley.

www.idx.co.id 